\title{
Humic Substances and Mineral-Associated Soil Organic Carbon As Influenced By Land Use in Southeastern Adamawa State, Nigeria
}

\author{
G. Y. Jamala ${ }^{1 *}$ and D. O. Oke ${ }^{2}$ \\ ${ }^{1}$ College of Agriculture, Ganye, Adamawa State, Nigeria \\ ${ }^{2}$ Federal University of Technology Akure, Ondo State, Nigeria
}

\begin{abstract}
Land use management has been observed to affect labile, stable and humified soil organic matter fractions, but the magnitude of these changes has not been established in the Southern Guinea savanna of Adamawa State, northeastern Nigeria. The study investigated effects of five land use management systems (undisturbed natural forest, crop land, grazing reserve, forest plantation and fallow land) on the status of humic substances and mineral-associated soil organic carbon. Three transects that are $100 \mathrm{~m}$ apart were cut in each of the study site and four sampling plots of $20 \mathrm{~m} \times 20 \mathrm{~m}$ in dimension were laid in alternate positions along each transect at $50 \mathrm{~m}$ interval. Soil core samples were collected diagonally at a depth of 0-15, 15-30, 30-45 and $45-60 \mathrm{~cm}$ and at three points in each plot using a $3 \mathrm{~cm}$ diameter soil auger. These results showed that both mineral-associated and humified organic matter are better protected under natural forest, plantation and grazing reserve and consequently less vulnerable to mineralization. The study revealed that seven years fallow contribution to soil organic carbon was minimal. This might be attributed to several factors such as livestock grazing, incidence of annual bush burning and cutting of vegetation for fuel wood. The relationship between stable soil organic carbon and various soil nutrients indicates that positive correlation exists. This shows that availability of humic, fulvic acid, exchangeable magnesium, exchangeable calcium, total phosphorus, cation exchange capacity and total nitrogen depend to some extent on the status of mineral-associated soil organic carbon. The content of humic was significantly influenced by land use and soil depth. Highest humic acid content $(17.42 \mathrm{~g} / \mathrm{kg})$ was recorded under plantation in the soil surface layer $(0-15 \mathrm{~cm})$, followed by natural forest $(15.16 \mathrm{~g} / \mathrm{kg})$, grazing reserve $(14.16 \mathrm{~g} / \mathrm{kg})$, and fallow land $(12.31 \mathrm{~g} / \mathrm{kg})$. The fulvic acid content also followed the same pattern as obtained for humic acid. The highest \%mineral associated soil organic carbon was recorded for plantation and natural forest at the surface layer $(0-15 \mathrm{~cm})(1.19$ and 1.15 respectively), followed by the grazing reserve (1.12). The crop land and the fallow land recorded 0.95 and 0.87 respectively. There exist differences across land use types in their potentials of storing total, particulate, mineral-associated organic carbon and humic substances in the Southern Guinea Savanna soils of Adamawa State, Nigeria. From the results it was noted that, natural forest, plantation and grazing reserve had potentials for storing organic carbon of appreciable concentration. This result provides valuable information for implementing tillage practices (such as zero tillage) that can favour carbon sequestration and improve soil quality.
\end{abstract}

Key words: Land Use, Humic substances, Mineral-associated soil organic carbon, Influence

\section{Introduction}

World soils are important reservoirs of active carbon and play a major role in the global carbon cycle. As such, soil can be either a source or sink for atmospheric $\mathrm{CO}_{2}$ depending on land use and the management of soil and vegetation (Lal, 2005). Soil organic carbon (SOC) represents the largest terrestrial organic C pool and globally contains over 1550 Pg Carbon (A Pg is equal to 1000 million metric tons) (Lal, 2008), and this pool attracts considerable attention because of its potential to sequester Carbon (Baker et al., 2007). The conversion of native forests for cultivation is usually accompanied by a decline in organic matter and soil structure deterioration (Resck et al., 2008). Other authors also maintained that conversion of natural ecosystems to agriculture is known to cause large losses of SOC, but the SOC losses also depends on land use (Ogle et al., 2005; Bayer et al., 2006; Dolan et al., 2006). In addition to changes in structure, organic matter reduction is associated with negative effects on nutrient concentrations (Ashagrie et al., 2007), water storage (Resck et al., 2008 ) and the emission of greenhouse gases (Lal, 2006).

In a previous study conducted by Alexandra and Jose (2005) they stated that, converting grassland and forest plantations to arable cropping results in the loss of $30 \%$ of the soil organic carbon (SOC) originally present in the soil profile. This is an indication that continuous cultivation of these soils can accelerate depletion of the soil organic carbon content. It is obvious that, under natural conditions organic matter (OM) is returned to soil through leaf droppings particularly in the deciduous plants. Before the forest is cleared, a closed nutrient cycle exists in the soil-forest system. Within this system, most nutrients are stored in the biomass and topsoil, 
and a constant cycle of nutrient transfer from one compartment of the system to another operates through the physical and biological processes of rain-wash (i.e. foliage leaching), litterfall; root decomposition, and plant uptake (Nair, 1993)

Most studies use the content of total organic carbon (TOC) to quantify the stocks and changes in organic matter. In many cases, the changes resulting from land use are not duly reflected in TOC values (Roscoe and Buurman, 2003),

The soil organic matter (SOM) is located in different compartments that have different recycling times and forms of protection (Duxbury et al., 1989). Soil organic matter can be analyzed on the basis of the different fractions. Changes in the levels of organic matter, caused by land use, can be better understood by alterations in the different compartments (Figueiredo et al., 2010).

In recent decades, several techniques have been refined to separate the different fractions, trying to identify labile and stable fractions, and their location in the soil structure (Roscoe and Machado, 2002). One such technique, the physical fractionation allows the separation of particulate organic matter (labile) composed of readily available material for decomposition by microbial attack, e.g., leaves, roots, animal remains and mineral-associated organic matter soil (stable) (Cambardella and Elliott, 1992).

These fractions have been used in studies involving the storage of SOM under different management systems (Bayer et al., 2004; Costa et al., 2004; Conceição et al., 2005; Vieira et al., 2007; Sá and Lal, 2009), specifically on water-stable aggregates (Ashagrie et al., 2007). It has been emphasized that these fractions can be used as an attribute of soil quality (Conceição et al., 2005) and sensitivity and as an indicator of changes caused by farming (Ashagrie, et al., 2007). Vieira et al., (2007) showed that particulate organic matter (>53 $\mu \mathrm{m})$ can be used to determine the index that measures the lability of organic matter. The influence of SOM on aggregate formation and stability is proven, although the existing fractions act differently in these processes (Baldock, 2002). The particulate fraction acts as a cementing agent, to stabilize macroaggregates and as intraaggregate protection of the proper organic matter (Six et al., 2002). Adejuyigbe et al., (2000) pointed out that particulate organic carbon is a more labile fraction of the soil organic carbon which is the most readily formed and when it decomposes, it serves as an important substrate for mineralization process in the soil. The level of this fraction therefore, could be an essential determinant of the fertility status of savanna soils.

Costa et al., (2004) found differential contributions of total organic and particulate organic carbon (more labile) in the formation of soil aggregates. In a study of Bayer et al., (2004), organic carbon in the particulate organic matter (POC) $(>53 \mu \mathrm{m})$ indicated management changes with greater sensitivity than TOC. Mineral-associated soil organic carbon is the soil separates that passed through the $53 \mu \mathrm{m}$ sieve during separation of particulate organic carbon. Bayer et al., (2001) found that, the $\mathrm{C}$ and $\mathrm{N}$ pools in mineral-associated soil organic carbon increased several times more than the particulate organic carbon fraction caused by greater physical recalcitrance of mineral-associated soil organic carbon to biological decomposition. The mineral-associated soil organic carbon is an excellent atmospheric carbon reservoir which is less affected by conventional tillage practices, and has smaller transference of soil $\mathrm{C}$ to the atmosphere.

Bayer et al., (2006) further maintained that, the non significant effect of tillage on carbon stocks in mineralassociated soil organic matter is probably related to the high stability of this fraction to biological decomposition due to interaction with various charge minerals.

Management decisions that reduce tillage intensity, maximize residue return, eliminate bare fallow, and reduce water stress with irrigation (Follet, 2001; Hermle et al., 2008) have all been suggested to increase SOC stocks and mitigate greenhouse gas (GHG) emissions, with soils serving as a Carbon sink for atmospheric $\mathrm{CO}_{2}$ (West and Marland, 2002; Ogle et al., 2005; Zinn et al., 2005).

Savannas are a major component of the Earth's vegetation and occupy large areas in Sub-Saharan Africa. The savanna biome is characterized by the co-dominance of trees and grasses, but ranges from grasslands where trees are virtually absent to more forest-like ecosystems where trees are dominant. Most of the savanna areas are natural ecosystems; however, they can also be formed by the degradation of tropical forests by burning, grazing and deforestation.

Humic substances (HS) make up a large portion of the dark matter in humus and are complex colloidal supramolecular mixtures (Piccolo, 1996, 2001; MacCarthy, 2001). These substances arise by the microbial degradation of biomolecules (lipids, proteins, carbohydrates, lignin) dispersed in the environment after the death of living cells. Humic substances may chelate multivalent cations such as Magnesium ${ }^{2+}$, Calcium $^{2+}$, and Iron $^{2+}$. By chelating the ions, they increase the availability of these cations to organisms, including plants.

Humic substances play an important role from the agronomy point of view. They influence significantly the quality and productivity of the soil. In addition to the improvement of the soil's physical properties and moisture conditions, HS also show a high Base Exchange capacity, which is important for soil fertility (Lotosh, 1991, Zhang and He, 2004).

Currently, humic materials are used as additives in fertilizers (García et al., 1994, Madejon et al., 2001, Albiach et al., 2001, Arancon et al., 2004). Different salts of humic substances, such as calcium humate, were used to 
increase soil fertility (Buckau et al., 2000). Another role of humic substances lies in the enhancement of the quality of soils when they are very poor in organic matter. Previous research shows that humic acid can be used as farm animal feed (Kocabagli et al., 2002).

Soil organic matter is composed of different compartments which differ from each other in biochemical composition, biological stability and carbon turnover rates (Paustian et al., 1992). The humified SOM (Humic, Fulvic and Humin) represents the most microbially recalcitrant and thus stable reservoir of organic carbon (OC) in soil and an important component that controls nutrient absorption and release, and for the control of soil erosion by water and wind (Piccolo et al., 1999).

Most studies on SOM dynamics in the tropics have focused on its absolute amount without recourse to their chemical fractions (Scholes et al., 1997). However, not much information is available on chemical characteristics of humic substances and mineral-associated organic carbon and their modifications when forested sites are cleared for intensive cultivation, especially in the savannas and also when marginal land is afforested. Yet SOM and HAs, in particular, play important roles in these soils where 1:1, low activity clays, and low cation exchange capacity (CEC) are common. In these conditions, more than $70 \%$ of the CEC of such soils and, hence, of their chemical fertility is attributed to SOM (Asadu et al., 1997). Soil monitoring is needed in order to assess the effects of land use change, as well as changes at the level of management types. Therefore, this study was carried out to characterize the humified OM fractions and mineral-associated soil organic carbon from natural forest, fallow land, grazing reserve, plantation and crop land soils of the southern guinea savanna of Adamawa State, Nigeria

\section{The Study Area}

\section{Materials And Methods}

The study was carried out in and around Gumti sector, the northern half of Gashaka-Gumti National Park, covering Toungo local government and Jada local government areas of Adamawa State. Toungo local government lies between latitude $8^{\circ} 7^{\prime}$ and longitude $12^{\circ} 3^{\prime}$ East. It is bounded by Ganye to the north, Taraba state to the west and south and to the east the Republic of Cameroon. It has a land mass of $5479.5 \mathrm{~km}^{2}$ and a population of 52,040 (Adebayo, 1999; NPC, 2007). Jada local government lies between latitude $8^{\circ} 46^{\prime} \mathrm{N}$ and longitude $12^{\circ} 9^{\prime}$ East. It is bounded by Ganye to the east, Mayo-belwa and Taraba state to the west, Toungo to the south and to the east Republic of Cameroon (Adebayo, 1999). It has a population of 171, 672 (National Population Commission, 2007).

\section{Climate}

The area received an annual rainfall of 1000-1200 mm. Rainfall distribution is unimodal, with much of the rain falling between April and November. Day time temperatures may drop below $18^{\circ} \mathrm{C}$ at higher altitudes and gradually rise to $40^{\circ} \mathrm{C}$. The rainy season is followed by a dry season. During this period, the area comes under the strong influence of the hammattan (November and March) a dry dusty wind blows from Sahara Desert and temperatures may be significantly cooler (Gashaka Gumti National Park, 2010).

\section{Site Selection and Sampling procedure}

The study area consists of five (5) selected sites; these include undisturbed natural forest, fallow land, grazing reserve, afforested land and a crop land. The undisturbed natural forest is strictly restricted as a National Park and hence no crop cultivation. The crop land is extensively cultivated with crops such as Maize, Sorghum, Cowpea, Arachis hypogea, Yam and livestock grazing is usually carried out on the site. In the grazing reserve no crop cultivation, the site is exclusively reserve for livestock grazing. The plantation was established with Gmelina arborea in 1993 and strictly protected against wildfire. Fallow land was left under natural fallow for seven years, livestock grazing and fetching of fuel wood also takes place. This site was under cultivation with crops such as Arachis hypogea, Yam, Maize, Sorghum and Cowpea. Prior to soil sampling, soil profile studies was carried out and the profile morphological characteristics of the dominant soil types in the study areas described based on (World Reference Base, 2006).

Systematic strip sampling was employed in laying out the plots. Three transects that are $100 \mathrm{~m}$ apart were cut in each of the study site and four sampling plots of $20 \mathrm{~m} \times 20 \mathrm{~m}$ in dimension were laid in alternate positions along each transect at $50 \mathrm{~m}$ interval. Soil core samples were collected diagonally at the depths of $0-15$, $15-30,30-45$ and $45-60 \mathrm{~cm}$ and at three points in each plot using a $3 \mathrm{~cm}$ diameter soil auger. Samples from each plot at each depth were bulked and the composite soil samples taken and analyzed in the laboratory for humic, fulvic acids, particulate soil organic carbon, mineral associated soil organic carbon and other physico-chemical soil properties. A total of forty eight (48) composite samples from each site were properly labeled for ease of identification. 


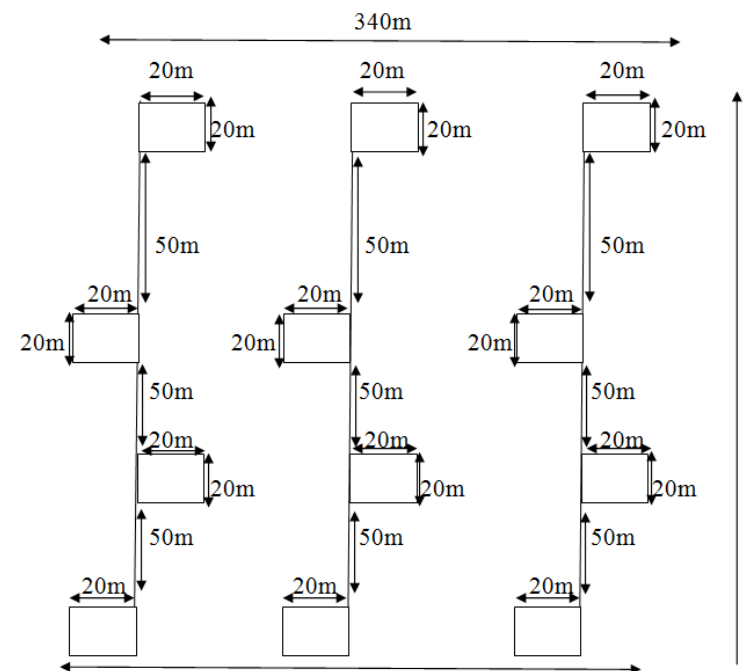

Fig. 1: Systematic Strip Transect Sampling Technique and Plot Layout

\section{Design of the Study}

The experiment was laid out in Randomized Complete Block Design (RCBD). The land use types constituted the treatments while soil depths constituted the blocks.

\section{Physical and chemical soil analyses \\ Fractionation of soils for separation into particulate and mineral size fractions}

The process of soil physical fractionation was based on the methodology proposed by Cambardella and Elliott (1992). $50 \mathrm{~g}$ of $\geq 2 \mathrm{~mm}$ soil sample was transferred into a $250 \mathrm{~m} \ell$ sample bottle and $105 \mathrm{~m} \ell$ distilled water added. Soil suspension was then washed through a $>53 \mathrm{~mm}$ sieve and the coarse fraction was separated. The soil samples above the $53 \mu \mathrm{m}$ sieve were considered particulate soil organic matter (SOM) while, those that pass through the sieve mineralized SOM. The particulate $(\geq 53 \mu \mathrm{m})$ and mineral $(<53 \mu \mathrm{m})$ soil fractions were dried in an oven at $100^{\circ} \mathrm{C}$, and analyzed for organic carbon using the wet oxidation method.

\section{Organic carbon determination in the various fractions}

Organic carbon was determined in the bulk soil, $\geq 53 \mu \mathrm{m}$ and $<53 \mu \mathrm{m}$ soil fractions as total organic carbon (TOC), particulate organic carbon (POC) and mineral organic carbon (MOC) respectively, using the wet oxidation method of Walkley and Black (1934). One gram of soil sample was weighed into a 250mls conical flask, $10 \mathrm{mls}$ of $1 \mathrm{~N}$ potassium dichromate added with the aid of a pipette, thereafter, $20 \mathrm{mls}$ of conc. Sulphuric acid added and allowed to cool to room temperature. $100 \mathrm{mls}$ of distilled water followed by $10 \mathrm{mls}$ of orthophosphoric acid was also added, after which $0.2 \mathrm{~g}$ of Sodium fluoride and 5 drops of diphenylamine indicator were added. The sample was titrated against $0.5 \mathrm{~N}$ ferrous sulphate.

The colour change (end point) to bottle-green and the organic carbon calculated using the following formula:

$\mathrm{OC}=\frac{B-T \times F \times 0.39}{W}$

Where:

$\mathrm{B}=$ Blank titre value

$\mathrm{T}=$ Sample titre value

$\mathrm{F}=$ Strength of Ferrous sulphate

$\mathrm{W}=$ Weight of sample.

$0.39=$ Constant

\section{Routine Soil Analysis}

The samples were also analyzed for $\mathrm{pH}(1: 2.5$ soil to water ratio) using glass electrode $\mathrm{pH}$ meter as described by Bates (1954), particle size was determined using hydrometer method as described by (Bouyoucos 1951). Available Phosphorus was extracted with $1 \mathrm{~N} \mathrm{NH}_{4} \mathrm{~F}$ and $0.5 \mathrm{~N} \mathrm{HCl}$ (Bray and Kurtz, 1945) and measured at the wavelength of $660 \mathrm{~nm}$. The titrimetric method was used for the determination of Calcium and Magnesium in the soil as described by Black, (1965) while the regular Macro-Kjeldahl Method as described by Black (1965) was used for the determination of soil total Nitrogen. Potassium and Sodium were determined in $1 \mathrm{~N}$ neutral $\mathrm{NH}_{4} \mathrm{OAc}$ soil extract using Flame Photometry and Exchangeable acidity was determined using the titration 
method as described by Mclean (1965). The effective cation exchange capacity and cation exchange capacity (CEC) was determined by summation method.

\section{Method of Extraction of Humic Substances}

The simple and rapid method of isolating humic substances as described by Shamsuddin et al., (2009). 5 grams of soil samples was transfer into a polyethylene centrifuge bottles $(250 \mathrm{ml})$ and $50 \mathrm{ml} 0.1 \mathrm{M} \mathrm{NaOH}$ solution added and bottle stopped tightly with a rubber stoppers. The samples were equilibrated at room temperature $\left(25^{\circ} \mathrm{C}\right)$ on a reciprocal mechanical shaker. The extraction period ranges from 4, 8, 12, 16, 20 and 24hours. At the end of each extraction period, the samples were centrifuged at 16, $211 \mathrm{G}$ for 15 minutes. The dark-coloured supernatant liquors decanted, the $\mathrm{pH}$ of the solutions adjusted to 1.0 with $6 \mathrm{M} \mathrm{HCL}$ and the humic acid (HA) allowed to stand at room temperature. At the end of each fractionation period, the excess supernatant liquors (Fulvic acid) were siphoned off from the acidified extracts. The remainder of the suspensions containing the HA was transfer to polyethylene bottles and centrifuge at $16,211 \mathrm{G}$ for 10 minutes. The HA samples were purified by washing them in $50 \mathrm{ml}$ of distilled water through centrifugation at $16,211 \mathrm{G}$ for 10 minutes to reduce mineral matter (e.g., $\mathrm{Na}^{+}$) and $\mathrm{HCl}$ (used during acidification). This procedure was repeated 5 times after which the washed HA samples were oven dried at $40^{\circ} \mathrm{C}$ to a constant weight, weighed and yields expressed as $\mathrm{g} / \mathrm{kg} \mathrm{HA}$ and FA (fulvic acid) in the soil samples.

\section{Statistical Analyses}

Data collected were subjected to analysis of variance (ANOVA) to determine statistical differences of selected soil properties. Correlation analysis was also employed to relate humic substances and mineral associated soil organic carbon to various soil nutrient elements. The Statistical analysis was performed with SPSS (V. 18), Mean separation was performed with Duncan's Multiple Range Test (DMRT) at $p<0.05$.

\section{Results}

\section{Influence of land use on the status of humic substances and carbon fractions}

The results of the influence of land use management on the status of humic substances and carbon fractions are shown in Table 1. The results of the analysis of variance (ANOVA) show that there was significant difference $(\mathrm{P}<0.05)$ in the status of humic acid, fulvic acid, \%total organic carbon, \% particulate organic carbon and $\%$ mineral associated organic carbon with respect to land use management. The highest humic acid and fulvic acid content was recorded for plantation $(8.75$ and $52.50 \mathrm{~g} / \mathrm{kg}$ soil), followed by the natural forest $(6.38$ and $40.97 \mathrm{~g} / \mathrm{kg}$ soil), grazing reserve (5.64 and $33.83 \mathrm{~g} / \mathrm{kg}$ soil), fallow land $(5.30$ and $31.80 \mathrm{~g} / \mathrm{kg}$ soil) and crop land (3.36 and $20.13 \mathrm{~g} / \mathrm{kg}$ soil) respectively. The result follows a decreasing order with land use management. Thus, Plantation $>$ Natural forest $>$ Grazing reserve $>$ Fallow land $>$ Crop land. For percentage particulate organic carbon (labile fraction), the highest $(0.55)$ was obtained in the natural forest, followed by the grazing reserve, plantation and crop land $(0.43,0.42$ and 0.39$)$ and fallow land $(0.32)$ respectively. Thus, Natural forest $>$ Grazing reserve $=$ Plantation $=$ Crop land $>$ Fallow land in a decreasing pattern. The highest \%mineral associated (stable fraction) organic carbon (0.70) was recorded for plantation, followed by the natural forest $(0.62)$, grazing reserve $(0.54$ and crop land $(0.52)$, followed by fallow land $(0.32)$ in a decreasing order respectively. Thus, Plantation $\geq$ Natural fores $>$ Grazing reserve $=$ Crop land $\geq$ Fallow land.

\section{Correlation of percent mineral associated organic carbon with humic acid, fulvic acid and other soil nutrients}

The relationship between percent mineral associated organic carbon with phosphorus, total exchangeable soil acidity, exchangeable Calcium, Humic and fulvic acids are presented in Table 2. Phosphorus was positively correlated with \%mineral associated carbon $(\mathrm{r}=0.86)$. Total exchangeable acidity, exchangeable Calcium, Humic acid, fulvic acid, \%total Nitrogen, exchangeable Magnesium and cation exchange capacity were also positively correlated with \%mineral associated carbon $(r=0.21, r=0.24, r=0.94, r=0.94, r=0.14, r-0.40$ and $\mathrm{r}-0.40$ ) respectively.

\section{Effects of soil depth and land use on humic substances and organic carbon fractions}

The effects of soil depth and land use management on humic substances and organic fractions are shown in Table 3. The results of the analysis of variance show that there was significant difference $(\mathrm{P}<0.05)$ in the contents of humic acid, fulvic acid, \%particulate soil organic carbon and \%mineral associated soil organic carbon with respect to soil depth and land use management. The content of humic acid was significantly influenced by land use and soil depth. Highest humic acid content $(17.41 \mathrm{~g} / \mathrm{kg})$ was recorded under plantation in the soil surface layer $(0-15 \mathrm{~cm})$, followed by natural forest $(15.16 \mathrm{~g} / \mathrm{kg})$, grazing reserve $(14.16 \mathrm{~g} / \mathrm{kg})$, fallow land $(12.31 \mathrm{~g} / \mathrm{kg})$ respectively. The subsurface layer of the plantation recorded the second highest content of humic acid $(13.33 \mathrm{~g} / \mathrm{kg})$, followed by the natural forest $(8.13 \mathrm{~g} / \mathrm{kg})$. Subsurface layers of the grazing reserve and 
fallow land 15-30, 30-45 $\mathrm{cm}$ had the same content of humic acid $(3.42,3.46 \mathrm{~g} / \mathrm{kg}$ ) respectively. The last subsurface layer of the plantation and the natural forest $30-45$ and $45-60 \mathrm{~cm}$ recorded the same and lowest content of humic acid (2.13 and $2.01 \mathrm{~g} / \mathrm{kg}$ ) followed by the fallow land $(1.97 \mathrm{~g} / \mathrm{kg})$, crop land and grazing reserve ( 1.33 and $1.11 \mathrm{~g} / \mathrm{kg}$ respectively). The fulvic acid content also followed the same pattern as obtained for humic acid. The surface layer of the plantation $(0-15 \mathrm{~cm})$ depth has the highest content $(104.46 \mathrm{~g} / \mathrm{kg})$ of fulvic acid, followed by the natural forest $(90.96 \mathrm{~g} / \mathrm{kg})$.

The results of analysis of variance revealed that there was significant difference $(\mathrm{P}<0.05)$ in the contents of \%particulate organic carbon and \%mineral associated soil organic carbon with soil depth and land use type (Table 3). The highest (1.19 and 1.15) \%mineral associated soil organic carbon was recorded for plantation and natural forest respectively at the surface layer $(0-15 \mathrm{~cm})$, followed by the grazing reserve (1.12). The crop land and the fallow land recorded $0.95 \%$ and $0.87 \%$ respectively. The subsurface layer $(15-30 \mathrm{~cm})$ of the plantation recorded the highest $0.84 \%$ mineral associated soil organic carbon followed by the crop land and the natural forest ( 0.75 and 0.70 respectively). The grazing reserve and the fallow land subsurface layer (15$30 \mathrm{~cm}$ and $30-45 \mathrm{~cm}$ ) had the same contents of \%mineral associated soil organic carbon in a decreasing pattern ( 0.32 and 0.29 respectively). Also, the subsurface layers of the plantation and the natural forest 45-60 and 30$45 \mathrm{~cm})$ had the same contents of \%mineral associated soil organic carbon ( 0.38 and 0.31$)$ respectively.

\section{Discussion}

Humic substances consist of the humic acid, fulvic acid and humin. These make up a large portion of the dark matter in humus and are complex colloidal supramolecular mixtures (Piccolo, 1996; 2001; MacCarthy, 2001). These organic substances play an important role from the agronomy point of view. They influence significantly the quality and productivity of the soil. In addition to the improvement of the soil's physical properties and moisture conditions, humic substances also show a high Base Exchange capacity, which is important for soil fertility (Lotosh 1991, Zhang and He, 2004).

The results of the analysis of variance show that there was significant difference $(\mathrm{P}<0.05)$ in the contents of humic acid, fulvic acid (passive fraction soil organic carbon), \%total soil organic carbon, $\%$ particulate (labile fraction) and \%mineral associated (stable fraction) soil organic carbon. The result of the status of humic and fulvic acids follows a decreasing pattern with land use type. Thus, Plantation $>$ Natural forest $>$ Grazing reserve $>$ Fallow land $>$ Crop land. This result indicates that land use is an important factor that controls the content and availability of humic substances in the soil. High content of humic and fulvic acids that was recorded in the plantation can be attributed to the organic matter returned to the soil through the leaf litter of Gmelina and most important as a deciduous plant which sheds leaf during the dry season. In a previous study conducted by Oluwatosin et al., (1999) they reported that, vegetation influences the quality of soils under it, which also in turn influence the growth and performance of crops. According to Juma, (1999) organic matter content, particularly the more stable (humic substances) increases the capacity of the soil to store water and sequester carbon from the atmosphere. Post and Kwon (2000) maintained that land use and soil management practices significantly influence soil organic carbon dynamics and carbon flux from the soil.

There was a marked decrease in the contents of humic acid and fulvic acid as a result of change in land use; Crop land recorded the lowest value of humic substances. This agrees with the findings of Alexandra and Jose (2005), who reported that conversion of grassland and forest plantations to arable cropping results in the loss of $30 \%$ of the soil organic carbon originally present in the soil. This shows that continuous cultivation of these soils can accelerate depletion of the soil organic carbon content.

Fallow remains one of the traditional methods of land use management system that is used for soil fertility restoration through the buildup of soil organic matter. In this study it was noted that the contribution of seven years fallow to the status of humic, fulvic acids and soil organic carbon was minimal. This might be attributed to several factors such as livestock grazing, incidence of annual bush burning and cutting of vegetation for fuel wood which is more frequent in the study area. The natural forest and the grazing reserve recorded a relatively high content of humic and fulvic acids due to accumulation and humification of organic matter under these land use types.

The results of correlation between percent mineral associated (stable fraction) soil organic carbon with phosphorus, total exchangeable soil acidity, exchangeable Calcium, Humic acid, fulvic acid, \%total Nitrogen, exchangeable Magnesium and cation exchange capacity showed positive relationship. This indicates that mineral associated organic carbon is both a carbon sink and also a source of soil nutrients. A high positive correlation exists between mineral associated organic carbon with humic acid, fulvic acid and phosphorus $\left(r^{2}=0.89, r^{2}=0.89\right.$ and $\left.r^{2}=0.74\right)$

The relationship between mineral-associated (stable fraction) soil organic carbon with various soil nutrients is a good indicator of soil fertility. Total organic carbon has been used as an indicator of soil fertility and productivity. The relationship between stable soil organic carbon and various soil nutrients in this study indicates that positive correlation exists. Some authors pointed out that this is attributed to the physical stability 
of aggregates in variable charge soils (Janzen et al., 1998; Bayer et al., 2001). The mineral-associated soil organic carbon has been reported to be very important in increasing and/or maintaining soil quality and determining the soil's potential to act as an atmospheric $\mathrm{CO}_{2}$ sink. Bayer et al., (2006) pointed out that this is probably related to high stability of this fraction to biological decomposition due to interaction with various charge minerals.

In a study conducted by Tipping (1994), he found out that humic acids have the ability to form complexes with ions such as $\mathrm{Mg}^{2+}, \mathrm{Ca}^{2+}, \mathrm{Fe}^{2+}$ and $\mathrm{Fe}^{3+}$. Ghabbour and Davies (2001) confirmed that the formation of (chelate) complexes is an important aspect of the biological role of humic acids in regulating bioavailability of metal ions. Yang et al., (2007) also found that soil organic matter plays an important role in nutrient availability and soil aggregate formation. The formation of stable macro aggregates is strongly linked to soil organic matter dynamics as well as nutrient supply. This shows that availability of humic, fulvic acids, exchangeable magnesium, exchangeable calcium, total phosphorus; cation exchange capacity and total nitrogen depend, to some extent, on the status of mineral-associated soil organic carbon. At the same time when the content of mineral-associated soil organic carbon is high this may also lead to a decrease in the availability of some soil nutrients. A negative relationship was observed between mineral-associated organic carbon and exchangeable soil potassium and sodium $(\mathrm{r}=-0.20 * *$ and $=-0.28 * *)$ respectively.

The content of humic was significantly influenced by land use and soil depth. Highest humic acid content $(17.42 \mathrm{~g} / \mathrm{kg})$ was recorded under plantation in the soil surface layer $(0-15 \mathrm{~cm})$, followed by natural forest $(15.16 \mathrm{~g} / \mathrm{kg})$, grazing reserve $(14.16 \mathrm{~g} / \mathrm{kg})$, fallow land $(12.31 \mathrm{~g} / \mathrm{kg})$ respectively. The fulvic acid content also followed the same pattern as obtained for humic acid. The highest \%mineral associated soil organic carbon was recorded for plantation and natural forest at the surface layer $(0-15 \mathrm{~cm})(1.19$ and 1.15 respectively), followed by the grazing reserve (1.12). The crop land and the fallow land recorded 0.95 and 0.87 respectively.

All the different land use types showed highest accumulation of the various carbon fractions in the surface layer $(0-15 \mathrm{~cm})$. Burle et al., (1997) also reported that highest soil organic matter increase on surface layers but soil organic matter storage in total soil profile was also positively affected. This high level of organic carbon stock in the surface layer could be due to the slow mixing of the soil and, the litter layer formed as a result of leaf-fall from the trees. In a 12-year experiment, Bayer et. al., (2000) found that by the third year, the increase in carbon and nitrogen stocks were minimal and occurred only in the $2.5 \mathrm{~cm}$ top layer, however, by the $5^{\text {th }}$ year, this effect had spread to the $7.5 \mathrm{~cm}$ depth. In the $9^{\text {th }}$ and $11^{\text {th }}$ year, carbon and nitrogen stocks increased through to $12.5 \mathrm{~cm}$ and $17.5 \mathrm{~cm}$ depths respectively. In addition, soil organic carbon storage in deeper soil layer has been related to the development of roots systems (Pillon, 2000) and to the amount of above ground biomass addition on the soil surface (Burle et, al., 1997) implying that the trees will normally improve in their respective organic carbon addition potentials, depending on the length of time and fallow period since the biomass increase with age. The organic carbon fractions were observed to decrease with depth. The top layer recorded the highest concentration of these fractions.

\section{Conclusion}

There exist differences across land use types in their potentials of storing total, particulate, mineralassociated organic carbon and humic substances in the Southern Guinea Savanna soils of Adamawa State, Nigeria. From the results it could be observed that, natural forest, plantation and grazing reserve had potentials for storing organic carbon of appreciable concentration.

The organic carbon fractions were observed to decrease with depth. The top layer recorded the highest concentration of these fractions. All the different land use types showed highest accumulation of the various carbon fractions in the surface layer $(0-15 \mathrm{~cm})$. This result provides valuable information for implementing tillage practices (such as zero tillage) that can favour carbon sequestration and improve soil quality

\section{Recommendations}

One strategy of increasing the humified and mineral-associated soil carbon in tropical soils is the use of management systems that provide large amounts of biomass, especially with deep root systems. Based on the results presented, pasture is an appropriate option, similar to natural forest in the amount of biomass it provides the soil with. However, the Gmelina arborea supported the highest accumulation of mineral-associated carbon making it a good candidate for trees which have carbon sequestration potentials in the savanna. 
Humic Substances And Mineral-Associated Soil Organic Carbon As Influenced By Land Use In

Table 1: Influence of land use management on the status of humic substances and carbon fractions

\begin{tabular}{|c|c|c|c|c|c|}
\hline Land use & $\% \mathrm{TO} / \mathrm{C}$ & $\%$ P.OC & $\% \mathrm{M.0C}$ & HA(g/kg) & $\overline{F A}(\mathrm{~g} / \mathrm{kg})$ \\
\hline Natural forest & $1.17 \mathrm{a}$ & $0.55 \mathrm{a}$ & $0.62 \mathrm{ab}$ & $6.83 \mathrm{ab}$ & $40.97 \mathrm{ab}$ \\
\hline Plantation & $1.12 \mathrm{ab}$ & $0.42 b$ & $0.70 \mathrm{a}$ & $8.75 \mathrm{a}$ & $52.50 \mathrm{a}$ \\
\hline Grazing reserve & $0.98 \mathrm{ab}$ & $0.43 b$ & $0.54 b c$ & $5.64 b$ & $33.84 b$ \\
\hline Crop land & $0.92 b c$ & $0.39 b$ & $0.52 b c$ & $3.36 \mathrm{c}$ & $20.13 c$ \\
\hline Fallow land & $0.73 \mathrm{c}$ & $0.32 \mathrm{c}$ & $0.42 \mathrm{c}$ & $5.30 \mathrm{bc}$ & $31.80 \mathrm{bc}$ \\
\hline
\end{tabular}

Means with the same letter along the columns are not significantly different (Duncan's Multiple Range Test $\mathrm{P}<0.05$ )

$\%$ TOC $\quad=\%$ Total organic carbon

$\%$ P.OC $\quad=\%$ Particulate organic carbon

$\%$ M.0C $\quad=\%$ Mineral associated organic carbon

$\mathrm{HA}(\mathrm{g} / \mathrm{kg}) \quad=$ Humic acid gram per kilogram soil

FA $(\mathrm{g} / \mathrm{kg}) \quad=$ Fulvic acid gram per kilogram soil

Table 2: Correlation Coefficients between total, particulate, mineral associated organic carbon, humic acid, fulvic acid, total available phosphorus, \%total Nitrogen and exchangeable cations

\begin{tabular}{|c|c|c|c|c|c|c|c|c|c|c|c|c|c|}
\hline & $\%$ TOC & \%P.OC & \%М.0С & $\% \mathrm{TN}$ & TEA & T-P & EK & ECa & EMg & ENa & ECE & HA & FA \\
\hline$\% \mathrm{TOC}$ & 1.00 & & & & & & & & & & & & \\
\hline$\%$ P.OC & $0.96^{* *}$ & 1.00 & & & & & & & & & & & \\
\hline \%M.0C & $0.99 * *$ & $0.91 * *$ & 1.00 & & & & & & & & & & \\
\hline$\% \mathrm{TN}$ & $0.15^{*}$ & $0.15^{*}$ & $0.14 *$ & 1.00 & & & & & & & & & \\
\hline TEA & $0,25 * *$ & $0.30 * *$ & $0.21 * *$ & $0.26^{*}$ & 1.00 & & & & & & & & \\
\hline T-P & $0.85 * *$ & $0.77 * *$ & $0.86^{* *}$ & 0.10 & 0.10 & 1.00 & & & & & & & \\
\hline EK & $-0.20 * *$ & $-0.24 * *$ & $-0.17 * *$ & -0.09 & $-0.19 * *$ & -0.03 & 1.00 & & & & & & \\
\hline ECa & $0.29 * *$ & $0.37 * *$ & $0.24 * *$ & -0.02 & 0.03 & $0.33 * *$ & $0.06 * *$ & 1.00 & & & & & \\
\hline EMg & $0.42 * *$ & $0.44 * *$ & $0.40 * *$ & $-0.35 * *$ & -0.07 & $0.18 * *$ & -0.08 & $0.27 * *$ & 1.00 & & & & \\
\hline $\mathrm{ENa}$ & $-0.28 * *$ & $-0.21 * *$ & $-0.31 * *$ & $0.18 * *$ & $0.22 * *$ & $-0.45 * *$ & $-0.70 * *$ & $-0.43 * *$ & $-0.18 * *$ & 1.00 & & & \\
\hline ECE & $0.45^{* *}$ & $0.51 * *$ & $0.40 * *$ & $-0.26 * *$ & -0.03 & $0.29 * *$ & -0.01 & $0.73 * *$ & $0.86^{* *}$ & $-0.36 * *$ & 1.00 & & \\
\hline HA & $0.93 * *$ & $0.86^{* *}$ & $0.94 * *$ & $0.17 *$ & $0.26^{* *}$ & $0.93 * *$ & 0.28 & $0.39 * *$ & $0.30 * *$ & $-0.50 * *$ & $0.42 * *$ & 1.00 & \\
\hline FA & $0.93 * *$ & $0.86^{* *}$ & $0.94 * *$ & $0.17 * *$ & $0.28^{* *}$ & $0.93 * *$ & 0.28 & $0.39 * *$ & $0.30 * *$ & $-0.50 * *$ & $0.42 * *$ & $0.97 * *$ & 1.00 \\
\hline
\end{tabular}

$* *$ Correlation if significant at 0.01 level, *Correlation is significant at 0.05 level

$\%$ TOC $\quad=\%$ Total organic carbon

$\%$ P.OC $\quad=\%$ Particulate organic carbon

$\%$ M.0C $\quad=\%$ Mineral associated organic carbon

TEA $\quad=$ Total exchangeable acidity

T-P = Total Phosphorus

$\% \mathrm{TN} \quad=\%$ Total Nitrogen

$\mathrm{EK}=$ Exchangeable Potassium

$\mathrm{ECa} \quad=$ Exchangeable Calcium

$\mathrm{EMg} \quad=$ Exchangeable Magnesium

$\mathrm{ENa} \quad=$ Exchangeable Sodium

ECE $=$ Cation exchange capacity

HA $\quad$ Humic acid

FA $\quad=$ Fulvic acid 
Humic Substances And Mineral-Associated Soil Organic Carbon As Influenced By Land Use In

\begin{tabular}{|c|c|c|c|c|c|}
\hline Soil depth $(\mathrm{cm})$ & Natural forest & Plantation & Grazing reserve & Crop land & Fallow land \\
\hline \multicolumn{6}{|c|}{ \% Total soil organic carbon } \\
\hline 0-15 & $1.94 \mathrm{a}$ & $1.91 \mathrm{a}$ & $1.87 \mathrm{a}$ & $1.46 \mathrm{a}$ & $1.55 \mathrm{a}$ \\
\hline 15-30 & $1.33 \mathrm{~b}$ & $1.26 \mathrm{~b}$ & $0.80 \mathrm{~b}$ & $1.12 \mathrm{~b}$ & $0.54 \mathrm{~b}$ \\
\hline $45-60$ & $0.70 \mathrm{c}$ & $0.65 \mathrm{c}$ & $0.80 \mathrm{~b}$ & $0.55 \mathrm{c}$ & $0.54 \mathrm{~b}$ \\
\hline $30-45$ & $0.70 \mathrm{c}$ & $0.65 \mathrm{c}$ & $0.38 \mathrm{c}$ & $0.54 \mathrm{c}$ & $0.34 \mathrm{c}$ \\
\hline \multicolumn{6}{|c|}{$\%$ Particulate soil organic carbon } \\
\hline $0-15$ & $0.77 \mathrm{a}$ & $0.73 \mathrm{a}$ & $0.76 \mathrm{a}$ & $0.50 \mathrm{a}$ & $0.68 \mathrm{a}$ \\
\hline $15-30$ & $0.62 b$ & $0.42 b$ & $0.39 b$ & $0.44 \mathrm{~b}$ & $0.24 \mathrm{~b}$ \\
\hline $45-60$ & $0.39 \mathrm{c}$ & $0.27 \mathrm{c}$ & $0.39 \mathrm{~b}$ & $0.31 \mathrm{c}$ & $0.24 \mathrm{c}$ \\
\hline $30-45$ & $0.39 \mathrm{c}$ & $0.27 \mathrm{c}$ & $0.185 \mathrm{c}$ & $0.31 \mathrm{c}$ & $0.11 \mathrm{c}$ \\
\hline \multicolumn{6}{|c|}{ \% Mineral-associated soil organic carbon } \\
\hline 0-15 & $1.15 \mathrm{a}$ & $1.19 \mathrm{a}$ & $1.12 \mathrm{a}$ & $0.95 \mathrm{a}$ & $0.87 \mathrm{a}$ \\
\hline 15-30 & $0.70 \mathrm{~b}$ & $0.84 \mathrm{~b}$ & $0.42 b$ & $0.75 b$ & $0.29 b$ \\
\hline 45-60 & $0.31 \mathrm{c}$ & $0.38 \mathrm{c}$ & $0.20 \mathrm{c}$ & $0.23 \mathrm{c}$ & $0.23 \mathrm{c}$ \\
\hline $30-45$ & $0.31 \mathrm{c}$ & $0.38 \mathrm{c}$ & $0.42 b$ & $0.23 \mathrm{c}$ & $0.29 b$ \\
\hline \multicolumn{6}{|c|}{ Humic acid (g/kg) } \\
\hline $0-15$ & $15.16 \mathrm{a}$ & $17.41 \mathrm{a}$ & $14.16 \mathrm{a}$ & $7.58 \mathrm{a}$ & $12.31 \mathrm{a}$ \\
\hline 15-30 & $8.13 b$ & $13.33 b$ & $3.42 b$ & $3.21 \mathrm{~b}$ & $3.46 \mathrm{~b}$ \\
\hline $30-45$ & $2.01 \mathrm{c}$ & $2.13 \mathrm{c}$ & $3.42 \mathrm{~b}$ & $1.32 \mathrm{c}$ & $3.46 \mathrm{~b}$ \\
\hline $45-60$ & $2.01 \mathrm{c}$ & $2.13 \mathrm{c}$ & $1.11 \mathrm{c}$ & $1.32 \mathrm{c}$ & $1.97 \mathrm{c}$ \\
\hline \multicolumn{6}{|c|}{ Fulvic acid (g/kg) } \\
\hline $0-15$ & $90.96 \mathrm{a}$ & $104.46 \mathrm{a}$ & $87.66 \mathrm{a}$ & $45.48 \mathrm{a}$ & $73.86 \mathrm{a}$ \\
\hline $15-30$ & $48.78 b$ & $79.98 \mathrm{a}$ & $20.52 b$ & $19.26 b$ & $20.76 b$ \\
\hline $30-45$ & $12.06 \mathrm{c}$ & $12.78 \mathrm{c}$ & $20.52 b$ & $7.92 \mathrm{c}$ & $20.76 b$ \\
\hline 45-60 & $12.06 \mathrm{c}$ & $12.78 \mathrm{c}$ & $6.66 \mathrm{c}$ & $7.92 \mathrm{c}$ & $11.82 \mathrm{c}$ \\
\hline
\end{tabular}

Means with the same letter along the columns are not significantly different (Duncan’s Multiple Range Test $\mathrm{P}<0.05$ )

\section{References}

[1]. Adejuyigbe, C.O., O.A. Agbeyangi and G.O Adeoye . (2000). Soil organic matter fraction and micro arthropod population under agroforestry trees with contrasting litter quality. Proceeding of the $26^{\text {th }}$ annual conference of the Soil Science Society of Nigeria. Ibadan, Oct $30^{\text {th }}-$ Nov. $3^{\text {rd }} 2000$. p. $203-206$.

[2]. Adebayo, A.A. (1999). Climate I\&II (Sunshine, Temperature, Evaporation and Relative humidity: In Adebayo, A.A. and Tukur, A.L. (eds) Adamawa in Maps, Paraclete publishers Yola-Nigeria. Pp $15-30$.

[3]. Agboola A.A. (2000). Advances in Soil Organic matter research. Proceeding of the $26^{\text {th }}$ annual conference of the Soil Science Society of Nigeria. Ibadan, Oct $30^{\text {th }}-$ Nov. $3^{\text {rd }} 2000$. p. $172-187$

[4]. Agboola A.A. and John A. I. Omueti (1982). Soil fertility problems and its management in tropical Africa, In Int. Conf. on Land Clearing and Develo. Proceedings Vol. 2, IITA, Ibadan, Nigeria

[5]. Albiach, R., Canet R., Pomares F.and Ingelmo F. (2001). Organic matter components, aggregate stability and biological activity in a horticultural soil fertilized with different rates of two sewage sludges during ten years. Biores. Technol. 77:109.114

[6]. Alexandra, B. and B. Jose. (2005). The importance of soil organic matter. Food and Agriculture Organization of the United Nations (FAO) Soils Bulletin.

[7]. Aluko A.P. (2001). Impact of Forestry on the nutrient status in degraded soil for environmental management at Onne: Proceeding s of the $27^{\text {th }}$ annual conference of the Forestry Association of Nigeria held at Abuja FCT $17^{\text {th }}-21^{\text {st }}$ Sept. p.100 - 109 .

[8]. Aluko A.P and J.A. Fagbenro, (2000). The role of tree species and Land use systems in organic matter and nutrient availability in degraded ultisol of Onne, South - South Nigeria. P. $289-293$.

[9]. Anderson, D. W., R.D., Heil C.V., Cole, and P.C., Deulsch .(1983). Identification and characterization of ecosystem at different integrative levels. In Lowrance, R., R. Todd, L. Asmussen, and R., Leonard (eds). Nutrient Cycling in Agricultural ecosystem. Spc. Publ.23, Gergia, USA: college of Agriculture, University of Gergia.

[10]. Annongu, .A A., J.K. Joseph and F.Liebert. (2004). Effect of anaerobic fermentation and lyle treated Prosopis africana seed meal on the nutritional and heamatological responses of harcoc chicks. Journal of raw materials Research (JORMAR) $(1): 33-41$.

[11]. Arancon N.Q., Edwards C.A., Bierman P., Welch C. and Metzger J.D (2004) Influences of vermicomposts on field strawberries: 1. Effects on growth and yields. Bioresource Techn. 93:145.153

[12]. Asadu, C.L.A., Diels, J. and Vanlauwe, B., (1997). A comparison of the contributions of clay, silt and organic matter to the effective CEC of soils in sub-Saharan Africa. Soil Sci. 162, 785- 794.

[13]. Ashagrie, Y.; Zech, W.; Guggenberger, G. \& Mamo, T. (2007). Soil aggregation, and total and particulate organic matter following conversion of native forests to continuous cultivation in Ethiopia. Soil Till. Res., 94:101- 108

[14]. Augustine, O.I and Joseph, I.M. (1992). The effects of tree canopy cover on soil fertility in a Nigerian Savanna. Journal of Tropical Ecology 8:329-338.

[15]. Baker, J.M., Ochsner, T.E., Venterea, R.T., Griffis, T.J., (2007). Tillage and soil carbon sequestration—what do we really know? Agric. Ecosyst. Environ. 118, 1-5.

[16]. Baldock, J.A. (2002) Interactions of organic materials and microorganisms with minerals in the stabilization of soil structure. In: Huang, P.M.; Bollag, J.M. and Senesi, N., eds. Interactions between soil particles and microorganisms: Impacts on the terrestrial ecosystem. Chichester, IUPAC, p.58-132.

[17]. Bates, R.G., (1954). Electrometric pH determination, John Wiley and Sons Inc. New York 43Pp

[18]. Bayer, C.,Mielniczuk, J., Amado, T.J.C., Martin-Neto, L., Fernandes, S.V., (2000). Organic matter storage in a sandy clay loam Acrisol affected by tillage and cropping systems in southern Brazil. Soil Till Res. 54, 101-109.

[19]. Bayer, C., L. Martin-Neto, J. Mielniezuk, C.N. Pillon, and L. Sangoi . (2001). changes in organic matter fractions under subtropical No - Till cropping systems. Soil Sceince Society of America Journal 65: 1473 - 1478.

[20]. Bayer, C.; Matin-neto; Mielniczuk, J. \& Javinato, A. (2004) Armazenamento de carbono em frações lábeis da matéria orgânica de um Latossolo Vermelho sob plantio direto. Pesq. Agropec. Bras., 39:677-683 Black, CA (ed) (1965). Methods of soil Analysis Agronomy No. 9 part 2 Amer. SOC. Agronomy, Madison Wisconsin 
[21]. Bayer, C., J. Mielniczuk, E. Giasson, L. Martin - Neto and A. Pavinato. (2006). Tillage Effects on particulate and mineral Associated organic matter in Two Tropical Brazilian soils. Communication in soil science and plant analysis 37:389-400

[22]. Bayer, C., Martin-Neto, L., Mielniczuk, J., Pavinato, A., Dieckow, J., (2006). Carbon sequestration in two Brazilian Cerrado soils under no-till. Soil Till. Res. 86, 237-245

[23]. Beniest, J. (2001). Agroforestry. In: Crop Production in Tropical Africa. By Giokint Graphics nv. p. 124

[24]. Black, C.A. (ed) (1965). Methods of soil Analysis Agronomy No. 9 part 2 Amer. SOC. Agronomy, Madison Wisconsin

[25]. Bouyoucos, G.H. (1951). A Recalibration of the Hydrometer for making mechanical Analysis of soils. Agronomy Journal 43: 434438

[26]. Brady N.C. and R.R. Weil (1999). The nature and properties of soils. $12^{\text {th }}$ ed. By precntice -Hall, Inc. New Jersy 07458, U.S.A . P. $336-489$.

[27]. Bray, R.H. and Kurtz, L.T. (1945). Determination of Total organic and available forms of phosphorus in soils. Soil Sci. 59: 39-45

[28]. Buckau G., Hooker P. and Moulin V., (2000) Versatile components of plants, soils and water In: Ghabbour E.A. and Davies G (eds): Humic Substances, RSC, Cambridge. 238 Pp.

[29]. Burle, M.L., J., Mielniczuk, and S., Fochi (1997). Effect of cropping system on soil chemicalcharacteristics, with emphasis on soil acidification. Plant Soil, 190: $309-316$.

[30]. Cambardella, C.A., and E.T., Elliott (1991). Physical isolation of organic matter fractions from grassland soil. In agronomy abstracts of the 1991 annual meetings, Denver, Colorado, October 27 - Nov. 1, 1991. Madison, Wisconsin, USA: American Society of Agronomy.

[31]. Cambardella, C.A., and E.T., Elliott . (1992). Particulate soil organic matter changes across a grassland cultivation sequence. Soil Sci.Soc.Am.J.,56:777-783

[32]. Chan K.Y. (1997). Consequence of changes in particulate organic carbon in vertisols under pasture and cropping. Soil Sci. Soc. Am. J. 61:1376-1382.

[33]. Charreau, C. and P. Vidal (1965). Influence de 1'Acacia albida Del. Sur-le soil. Nutrition Minerale et rendements desm 1 pennisetum au Senegal. Agric. Trop. 67:600-625.

[34]. Conceição, P.C.; Amado, T.J.C.; Mielniczuk, J. and Spagnollo, E. (2005) Qualidade dosolo em sistemas de manejo avaliada pela dinâmica da matéria orgânica eatributos relacionados. R. Bras. Ci. Solo, 29:777-788

[35]. Costa, F.S.; Bayer, C.; Albuquerque, J.A. and Fontoura, S.M.V. (2004). Aumento de matéria orgânica num Latossolo Bruno em plantio direto. Ci. Rural, 34:587-589,

[36]. Dan Cette, C. and J.F. Poulain (1968). Influence de1' acacia albida sur les fecteurs pedodimatiques et les rendem exat. Des. Cultures. Soil Afr. 13:197 - 239.

[37]. Dolan, M.S., Clapp, C.E., Allmaras, R.R., Baker, J.M. and Molina, J.A.E., (2006). Soil organic carbon and nitrogen in a Minnesota soils as related to tillage, residue and nitrogen management. Soil Till. Res. 89, 221-231.

[38]. Duxbury, J.M.; Smith, M.S. and Doran, J.W. (1989). Soil organic matter as a source and sink of plant nutrients. In: Coleman, D.C.; Oades, J.M. and Uehara, G., eds. Dynamics of soil organic matter in tropical ecosystems. Honolulu, University of Hawaii Press

[39]. Elliott, E.T., C.A Palm, D.E., Reuss and C.A., Monz . (1991). Organic matter contained in soil Aggregates from a Tropical Chrono Sequence: Correction for sand and light Fractions. Agric. Ecosystem Environ 34:443 - 51.

[40]. Elliott, E.T. and C.A., Cambardella (1992). Characteristics of biologically available organics. In Van Brehman, N.(ed) Decomposition and accumulation of organic matter in Terrestrial Ecosystems: A key process in Biogeochemistry and environment change

[41]. Fagbenro, J.A. (1979) Contribution of Organic Matter and Total Clay to CEC in three teak (Tectona grandis) plantation Soils in Southern Nigeria. Forestry Res. Inst. Nigeria, Research Paper (Forest Series)

[42]. Fagbenro, J.A., M.H.B. Hayes, I.A. Law and A.A. Agboola (1984) Extraction of soil organic matter and humic subs. From two Nigerian soils using three solvent mixtures. Paper presented at the $2^{\text {nd }}$ meeting of International Humic Substances Society, Birmingham

[43]. FAO, (2005a) Agroforestry parklands in Sub - Saharan Africa FAO corporative Document Repository p.243 - 253.

[44]. FAO (2005b) National Special Programme for Food Security, Abuja, 3 Pp

[45]. Feller, C., G. Burtin, B. Gerard, and J. Balesdent (1991). Utilization of des resins sodiques et des ultrasons le fractionnement granulometrique de la matiere organique des sols. Interets et limites. Sci. du Sol. 29:77 - 94.

[46]. Feller, C. (1993). Organic inputs, soil organic matter and functional soil organic compartments in low-activity clay soils in tropical zones. A proceeding of an internal symposium organized by the laboratory of soil fertility and soil biology, Katholieke universiteit leuven (k.U. Leuven) and the International Institute of Tropical Agriculture (IITA) and held in Leuven, Belgium, 4 - 6 Nov. 1991 P.77 - 88.

[47]. Figueiredo, C.C., D.V. Resck and M.A. Carneiro (2010). Labile and Stable Fractions of Soil Organic Matter under Management Systems and Native Cerrado. R. Bras. Ci. Solo. 34:907-916

[48]. Flaig, W., H. Beutelspacher, and E. Rietz (1975). Chemical composition and physical properties of humic substances, In J.E. Giescking (eds.) Soil components, Vol. 1, pp.1-219, Springer-Verlag, bedin, New York

[49]. Flaig, W. (1982). Soil Organic Matter of as a source Nutrients. In International Conference on Organic Matter and Rice Proceedings, Philippines, 27 Sept.-1 October

[50]. Follet, R.F., (2001). Soil management concepts and carbon sequestration in cropland soils. Soil Till. Res. 61, 77-92.

[51]. Garcia D., Cegarra J., Roig A., Abad M. (1994) Effects of the extraction temperature on the characteristics of a humic fertilizer obtained from lignite. Biores. Technol. 47:103.106

[52]. Gashaka Gumti National Park, (2010) A Wild World of Wonders! Taraba State, Nigeria. 50 Pp.

[53]. Ghabbour, E.A. and Davies, G. (eds., 2001) Royal Society of Chemistry, Cambridge, 69-78Pp.

[54]. Harmand J.M. and C.F. Njiti (1998). Effects dos Jacheres agroforestie res surles propritesd'un sol Ferrigineux et sur la production cerealiere. Agriculture et developpenment .18:21-29.

[55]. Hartmann, E.H. (1981). Application of the continuous How Stirred Cell Technique to the study of Sorption of inorganic cations by Hydrogen-Iron Exchanged Humic Preparations University of Birmingham, England

[56]. Hayes, M.H.B. and R.S. Swift (1978), The Chemistry of Soil Organic Colloids In :The Chemistry of soil constituents.Eds. Greenland, D.J. and Hayes, M.H.B. John Wiley and Sons, New York Pp 169-320

[57]. Hermle, S., Anken, T., Leifeld, J., and Weisskopf, P., (2008). The effect of the tillage system on soil organic carbon content under moist, cold-temperate conditions. Soil Till. Res. 98, 94-105

[58]. Janzen, H.H., C.A., Campbell, R.C. Izaurralde, B.H., Ellert, N. Juma W.B. McGill and R.P. Zentner (1998). management effect on soil C Storage on the Canadian prairies. Soil Till. Res. 47:181 - 195. 
[59]. Juma, N. G., (1999). Introduction to soil science and soil resources volume I in the series. "The pedosphere and its dynamics. A system approach to soil science" Salman production, Sherwood park. $335 \mathrm{Pp}$,

[60]. Kocabagli N., M. Alp, N. Acar, R. Kahraman (2002). The effects of dietary humate supplementation on broiler growth and carcass yield. Poult. Sci. 81: 227-230

[61]. Kononova, M.M. (1966). Soil Organic Matter, Its nature, its role in soil formation and in soil fertility, $2^{\text {nd }}$ edition, pergamon press, Oxford

[62]. Ladd J.N., R.C. Foster and J.O. Skjemstad (1993). Soil structure: Carbon and Nitrogen metabolism Geoderma 56, $401-434$.

[63]. Lal, R., B.T. Kang., F.R. Moorman, A.S.R. Juo, and J.C. Moomaw (1975). Soil Management problems and possible. In Soil Management in Tropical America State Univ . Releigh. . p. $372-408$.

[64]. Lal, R. (2005). No-till farming and environment quality. In: Simpósio sobre Plantio direto e Meio ambiente; Seqüestro de carbono e qualidade da agua, pp. 29-37. Anais. Foz do Iguaçu, 18-20 de Maio.

[65]. Lal, R., (2006). Soil carbon sequestration in Latin America. In: Lal, R.; Cerri, C.C.; Bernoux, M.; Etcheves, J. and Cerri, E. Carbon sequestration in soils of Latin America. New York, Food Products Press, p.49-64.

[66]. Lal, R., (2008). Carbon sequestration. Philos. Trans. R. Soc. B 363, 815-830.

[67]. Lotosh T.D. (1991). Experimental bases and prospects for the use of humic acid preparations from peat in medicine and agricultural production. (In Russian) Naucn. Dokl. Vyss. Skoly. Biol. Nauki 10: 99.103

[68]. MacCarthy, J. F. (2001). Subsurface transport of dissolved humic substances and associated ontaminants. In humic Substances a nd Chemical Contaminants, C. E. Clapp, M. H. B. Hayes, N. Sensi, P. R. Bloom, and P. M. Jardine. Soil Science Society of America, Madison, WI, Chapter 21, Pp 429-448.

[69]. Madejón E., R. López, J.M. and Murillo, F. Cabrera (2001). Agricultural use of three (sugar-beet) vinasse composts: effect on crops and chemical properties of a Cambisol soil in the Guadalquivir river valley (SW Spain). Agric. Ecosyst. Environm. 84: 55-65

[70]. Mclean, E. O. (1965). Aluminium in method of soil Analysis (ed. C.B. Black), pp 978-998. Agronomy, Madison, Wisconsin

[71]. Nair, P.K.R. (1993). An introduction to agroforestry, Kluwer Academic Publishers, Netherlands. 499 Pp

[72]. National Population Commission, NPC (2007). Federal Republic of Nigeria Official Gazette No. 24 Volume 94 Lagos, Nigeria.

[73]. Ogle, S.M., Breidt, F.J., Paustian, K., (2005). Agricultural management impacts on soil organic carbon storage under moist and dry climatic conditions of temperate and tropical regions. Biogeochemistry 72, 87-121.

[74]. Okojie J.A. (1997). Key note address: Forestry and the Environment: J. Trop Forest Resources. 13 (2): 5 -17.

[75]. Oluwatosin G.A., J.A. Adediran, and A.P. Aluko. (1999). Tree Species and Soil micro variability within a profile class in the Southern Guinea Savanna of South Western Nigeria. Journal of Tropical Forest Resources. 15(1): p. $174-185$.

[76]. Paustian, K., Parton, W.J. and Persson, J., (1992). Modeling soil organic matter in organic amended and nitrogen-fertilized longterm plots. Soil Sci. Soc. Am. J. 56, 476-488.

[77]. Piccolo A (1996). Humic substances in terrestrial ecosystems. Elsevier, Amsterdam Pp 689

[78]. Piccolo, A., Spaccini, R., Haberhauer, G. and Gerzabek, M.H., (1999). Increased sequestration of organic carbon in soil by hydrophobic protection. Naturwissenschaften $86,496-499$.

[79]. Piccolo, A. (2001) The Supramolecular structure of humic substances. Soil Science, 166:810-832.

[80]. Piccolo, A. (2002). "The Supramolecular structure of humic substances. A novel understanding of humus chemistry and implications in soil science". Advances in Agronomy 75: 57-134.

[81]. Pillon, C.N. (2000). Stocks and Quality of soil Organic Matter as Affected by No-Till Cropping System, doctorate thesis; Federal University of Rio Grande do Sul: Porto Alegre, 248 Pp

[82]. Post, W. M. and Kwon, W. M. (2000). Soil carbon sequestration and land use change: Process and Potential. Global change Biol., (6): $317-327$

[83]. Resck, D.V.S.; Ferreira, E.A.B.; Figueiredo, C.C. \& Zinn, Y.L. Dinâmica Da (2008). Matéria orgânica no Cerrado In: Santos, G.A.; Silva, L.S.; Canellas, L.P. \& Camargo, F.O., eds. Fundamentos da matéria organic do solo: Ecossistemas tropicais e subtropicais. 2.ed. Porto Alegre, Metrópole, p.359-417.

[84]. Roscoe, R., Buurman, P., (2003). Tillage effects on soil organic matter in density fractions of a Cerrado Oxisol. Soil Till. Res. 70, $107-119$.

[85]. Roscoe, R. and Machado, P.L.O.A. (2002). Fracionamento físico do solo em estudos da matéria orgânica. Dourados, Embrapa Agropecuária Oeste; Rio de Janeiro, Embrapa Solos, 86 Pp.

[86]. Rubaduka E.B., G. Cadisch and K.E Giller (1993). Mineralization of nitrogen in woody legume prunings and its recovery by maize. A proceeding of an internal symposium organized by the laboratory of soil fertility and soil biology, Katholieke universiteit leuven (k.U. Leuven) and the International Institute of Tropical Agriculture (IITA) and held in Leuven, Belgium, 4 - 6 Nov. 1991 p.181188 .

[87]. Sá, J.C.M. and lal, R. (2009). Stratification ratio of soil organic matter pools as an indicator of carbon sequestration in a tillage chronosequence on a Brazilian Oxisol. Soil Till. Res., 103:46-56

[88]. Scholes M.C., Martin R., Scholes R.J., Parsons D. and Winsted E. (1997). No and $\mathrm{N}_{2} \mathrm{O}$ emissions from savanna soils following the first simulated rains of the season. Nutr. Cycl. Agroecosyst. 48:115-122.

[89]. Schnitzer, M. and S.U. Khan, (1972). Humic substances in the Environment, Marcel Dekker, New York Pp 327

[90]. Shamsuddin R., O. H. Ahmed, K. Susilawa, N. Muhamad Ab and M. B. Jalloh (2009). Simple and Rapid Method of Isolating Humic Acids from Tropical peat soils American Journal of Applied Sciences 6(5): 820-823

[91]. Six, J., Feller, C., Denef, K., Ogle, S.M. and Sa, J.C.M., (2002). Soil organic matter biota and aggregation in temperate and tropical soils-effects of no-tillage. Agronomie 22, 755-775.

[92]. Sobulo, R A and O A Osiname (1982) Soil Properties and crop yields under continuous cultivation with different management systems, In Proceedings of Int. Conf. on Land Clearing and Development Vol. 2, IITA, Ibadan, Nigeria

[93]. Stevenson, F.J., (1965). Gross chemical fractionation of soil organic matter. In: Black, C.A., et al. (Eds.), Methods of Soil Analysis: Part 2. Chemical and Microbiological Properties. Amer. Soc. Agr., Madison.

[94]. Stevenson, F. J., and E.T. Elliott. (1989). Methodologies for Assessing the Quantity and Quality of Soil Organic Matter. In Coleman, D.C., J .M Oades, and U., Uehara (eds) Dynamics of soil organic in Tropical Ecosystem. Hawaii, USA: NIFTAL Project. $443 \mathrm{Pp}$

[95]. Swift M. J. and P.L Woomer (1993). Organic matter and sustainability: Definition and measurement. A proceeding of an internal symposium organized by the laboratory of soil fertility and soil biology, Katholieke universiteit leuven (k.U. Leuven) and the International Institute of Tropical Agriculture (IITA) and held in Leuven, Belgium, 4-6 Nov. 1991 P 1-3 - 18.

[96]. Tiessen, H. and J.W.B. Stewart (1983). Particle size Fractions of Organic mineral Complexes by Sedimentation and Density Techniques Geoderma 21:311 - 43 . 
[97]. Tilander, Y.(1993). Effects of mulching with A. Indica and Abizia lebbeck leaves on the yield of sorghum under seme-arid conditions in Burkina Faso. Agroforestry, 24: 277 - 293.

[98]. Tipping, E. (1994). "'WHAM - a chemical equilibrium model and computer code for waters, sediments, and soils incorporating a discrete site/electrostatic model of ion-binding by humic substances". Computers and Geosciences 20 (6): 973-1023

[99]. Uyovbisere, E.O. and K.A. Elemo (2002). Effect of tree foliage of locust bean (Parkia biglobosa) and neem (Azadirachta indica) on soil fertility and production of miaze in a Savanna alfisol. Nutrient Cycling in Agroecosystems 62:115-122.

[100]. Van der Meersch, M.K., R. Merckx and K. Mulongoy (1993). Evolution of plant biomass and nutrient content in relation to soil fertility changes in two alley cropping systems. Proceeding of an internal symposium organized by the laboratory of soil fertility and soil biology, Katholieke universiteit leuven (k.U. Leuven) and the International Institute of Tropical Agriculture (IITA) and held in Leuven, Belgium, 4 - 6 Nov. 1991.p.143-154

[101]. Vieira, F.C.B.; Bayer, C.; Zanatta, J.A.; Dieckow, J.; Mielniczuk, J. and He, Z.L. (2007). Carbon management index based on physical fractionation of soil organic matter in an Acrisol under long-term no-till cropping systems. Soil Till. Res., 96:195-204

[102]. Walkley, A and I A Black (1934). An examination of the Degtjarelf method for Determing soil organic Matter and proposed modification of the Chromic Acid Titration method. Soil Sci. 37: 29-38

[103]. West, T.O. and Marland, G., (2002). A synthesis of carbon sequestration, carbon emissions, and net carbon flux in agriculture: comparing tillage practices in the United States. Agric. Ecosyst. Environ. 91, 217-232.

[104]. World Reference Base (WRB) (2006). World Reference Base for Soil Resources: A framework for International Classification, Correlation and Communication. Food and Agriculture Organization of the United Nations. Rome, Italy, pp 145.

[105]. Yang Z., B.R. Singh, S., Hansen Z.Hu, and H. Riley (2007). Aggregate Associated sulphur fractions in long-term ( $>80$ years) fertilized soils. Soil Science Society of America. J.17(1) 163-170.

[106]. Zhang M. and Z. He (2004). Long-term changes in organic carbon and nutrients of an Ultisol under rice cropping in southeast China. Geoderma 118: 167.179

[107]. Zinn, Y.L., Lal, R. and Resck, D.V.S., (2005). Changes in soil organic carbon stocks under agriculture in Brazil. Soil Till. Res. 84 (1), 28-40.

\section{Acknowledgements}

The authors would like appreciate the permission granted by the authorities of Gashaka Gumti National Park, Toungo sector and the Department of Livestock/Forestry, Jada local government area, Adamawa State, Nigeria. We are also grateful to all the students of the Dept of Forestry Tech., College of Agriculture, Ganye, Adamawa State, who tirelessly assisted during the field work. 